\title{
Communication Planning of Langsa City Government in Building an Islamic and Environmentally Friendly City
}

\author{
Syukur Kholil ${ }^{1}$, Ahmad Thamrin Sikumbang ${ }^{2}$, Mawardi Siregar ${ }^{3}$ \\ ${ }^{1,2}$ Lecturer in State Islamic University of North Sumatera (UINSU), Medan, Indonesia \\ ${ }^{3}$ Ph.D Student in State Islamic University of North Sumatera (UINSU), Medan, Indonesia \\ sipirokpbujur76@gmail.com
}

\begin{abstract}
This study analyzes three points, namely: 1) communication planning conducted by the Langsa City government; 2) community participation in communication planning; and 3 ) the effectiveness of communication planning in realizing urban development that is Islamic and environmentally friendly. This research method is qualitative by collecting data through medalam interviews, observations and documentation studies. The results of this study: First, to create an Islamic and environmentally friendly city, communication planning conducted by the Langsa City government, namely analyzing field data, planning communication, and planning strategies implementation of communication that has been planned. Second, community participation in communication planning is directly by following Musrembang, FGD and public discussions and indirectly by representing their aspirations through council members in Langsa DPRK institution. Third, communication planning to realize the development of an Islamic and environmentally friendly Langsa City has not been effective, because the use of strengths and opportunities has not been able to be optimized to overcome the challenges of weaknesses, so the pace of development of the Langsa City has been slow.
\end{abstract}

Keywords: Communication planning; Islamic cities; environmentally friendly.

\section{Introduction}

Communication planning is one thing that is very urgent to do in urban development activities. This is important, because communication planning aims to help achieve programs effectively and efficiently. In developing urban areas, Khambali explains several things that had to be done, namely planning the construction of adequate facilities and infrastructure, so as to support social life and economic activities of the community. ${ }^{1}$

The city promises a prosperous life, so that it encourages some people to make the city the destination of migration. As a result, the population of the city is increasingly dense and the activities that occur therein are also higher. The higher activity that occurs in the city, also affects the quality of the environment. To maintain the quality of the city environment remains comfortable, clean and orderly, the government continues to strive to carry out development that aims to provide satisfaction for the population of the city.

Development must consider environmental preservation, or in other words maintain environmental balance. But development often results in damage to the city's ecosystems that have been well preserved. To maintain the balance of development with environmental sustainability, Langsa City Government undertakes Islamic and environmentally friendly development. Referring to the vision of "Turning Langsa into Civilized and Islamic Cities", the development of Langsa City is not only concentrated in the city center, but has expanded to the villages. In the city center, Langsa City Government built a shopping center that could make it easier for people to meet their daily needs, build environmentally friendly public spaces, and build recreation areas, community playgrounds, and educational facilities.

\footnotetext{
${ }^{1}$ Khambali, Model Perencanaan Vegetasi Hutan Kota (Yogyakarta: Penerbit Andi, 2017), pp. 13-14.
} 
The development of an Islamic and environmentally friendly city conducted by the Langsa City Government, supported by good communication planning. Community participation is encouraged to create an Islamic city and environmentally friendly. The harmony between the community and the government that is running the development program, is more easily realized by the presence of communication in the development program that is carried out. Langsa City Government takes steps in communicative approach to the community to realize the development of an Islamic and environmentally friendly Langsa City. On that basis, this article will elaborate more deeply about Langsa City Government's communication planning in building an Islamic and environmentally friendly city.

\section{Research Method}

This research is a qualitative research that focuses on seeing (observing) what happens at the research location (naturalistic setting). ${ }^{2}$ Lincon and Guba also call it naturalistic inquiry, because researchers tried to understand the object being studied as it is, not manipulated but understood through natural analysis. ${ }^{3}$ The aim is to understand in real terms, the focus of the problems that have been formulated, then reported in full, detailed and systematic, based on facts obtained from information sources, and natural settings observed. ${ }^{4}$ Data is collected from informants through in-depth interviews. Observations and documentation studies that are relevant to the research topic, are other techniques used to collect primary data, while the analysis uses Interpretative Phenomenological Analysis (IPA) techniques introduced by Jonathan A. Smith. ${ }^{5}$

\section{Result}

\subsection{Communication Planning of Langsa City Government in Building Islamic and Environmentally Friendly City}

Communication planning is the first step for all types of activities. Including starting development activities, communication planning is a very important part. Sean MacBride negates that communication becomes a cultural tool that causes social integration. With communication, attitudes and motivations someone will be encouraged or influenced to

\footnotetext{
${ }^{2}$ Jalaluddin Rakhmat, Metode Penelitian Komunikasi Dilengkapi Contoh Analisis Statistik (Bandung: Remaja Rosdakarya, 1984), p. 25.

${ }^{3}$ If you follow the logic of Lincoln and Guba's explanation, that ontologically, qualitative research is characterized by the fact that the researcher constructs / constructs the reality he sees. In qualitative research ideas, each person is involved in research, as participants or subjects together construct reality. See, Yvonna S. Lincoln and Egon G. Guba, Naturalistic Inquires (California: Sage Publications, 1985), pp. 70-91. See also, Dedy Mulyana, Metode Penelitian Kualitatif: Paradigma baru Ilmu Komunikasi dan Ilmu Sosial Lainnya (Bandung: Remaja Rosdakarya, 2004), pp. 157-159.

${ }^{4}$ John W Creswell, Research Design: Qualitative \& Quantitative Approach (California: Sage Publication, 1994), pp. $5-7$.

5 Jonathan A. Smith, et.all, Interpretative Phenomenological Analysis: Theory, Method and Research (California: Sage Publications, 2009), pp. 79-107.
} 
behave, and it will extend to other environments. That is why, individuals with their awareness will play a major role in development. ${ }^{6}$

Observing the opinion of Sean MacBride, the communication planning becomes very important, because communication planning has a close relationship with the development policies that have been designed by the government for the welfare of the community. Schramm, as quoted by Zulkarimein Nasution, also negated, that to improve the welfare of the community, development must be carried out, and the development must be informed to the community. ${ }^{7}$

Communication planning needs to be considered when carrying out development, so that the strategies used to convey the message will be more effective. Communication planning in development functions to analyze the strategies carried out. Communication planning is closely related to determining the methods used to communicate the message, whether through certain media and so on, so that the contents of the message delivered can make a change. The link between communication planning, strategy and goal achievement has an inseparable unity as illustrated below. Effective communication strategies related to communication planning. Everett M. Rogers (1985) mentions that communication is the basis of a nation's social change. Communication is seen as an extension of government planners and its main function is to get community support and their participation in implementing development plans. ${ }^{8}$

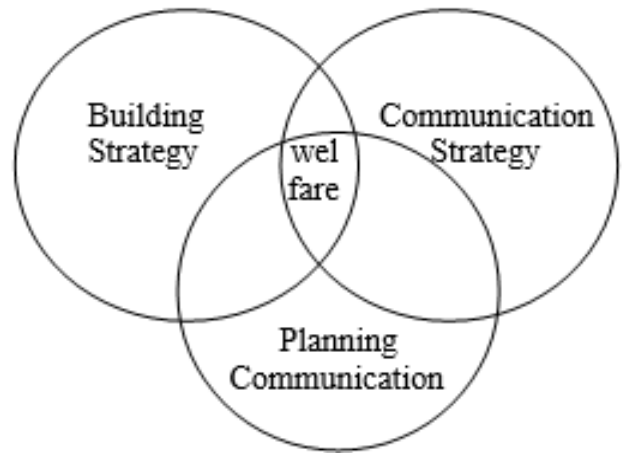

Figure 1. Relationship between Building Strategies, Communication Strategies and Communication Planning

Based on the findings in the field, there are four steps in the communication planning undertaken by Langsa City Government to develop an Islamic and environmentally friendly city. First, to map development problems based on field data. Second, plan communication. Third, plan the strategies carried out to implement the communication plan that has been designed. Fourth, set desired development goals and objectives.

Islamic city development is not only in the form of physical development, but a city that practices the values of Islamic teachings as the spirit of running all aspects of life. The

\footnotetext{
${ }^{6}$ Sean MacBride, Many Voices One World: Commnunication and Society Today and Tomorrow (London: Kogan Page, 1980), p. 14.

${ }^{7}$ Zulkarimen Nasution, Komunikasi Pembangunan: Pengenalan Teori dan Penerapannya (Jakarta: PT. Raja Grafindo Persada, 2002), p. 120.

${ }^{8}$ Everett M. Rogers dan F Ployd Shoemaker, Komunikasi Sambung Rasa (Jakarta: Pustaka Sinar Harapan, 1981), h. 37.
} 
realization is very clearly seen to manifest in the daily life of the community, even though it has not been optimal, because there are many challenges and obstacles faced by the government.

\subsection{Community Participation in Creating Development of Islamic and Environmentally Friendly Langsa City}

The new development paradigm in the era of regional autonomy encourages each district / city to develop partnerships and community participation. Community participation in development planning is very important, because the government cannot stand alone in realizing the development goals of Langsa City.

In Rencana Pembangunan Jangkan Panjang (Long Term Development Plan/RPJP) document, Rencana Pembangunan Jangka Menengah (Medium-Term Development Plan/RPJM) and Rencana Kerja Perangkat Kota (Langsa City Work Plan/RKPK) it is stated that cooperation and encouraging community participation in development is one of the strategies to realize the development goals of the Islamic and friendly Langsa City environment.

Based on field findings, there are three types of community participation in the development of Langsa City, namely participation in planning, participation in the implementation of development and participation in enjoying development. The participation is in the form of direct or indirect. Direct participation is carried out by the public by following Mustembang, FGD and public discussions. Indirect planning is carried out by the community by representing their aspirations through representation in the DPRK institution.

Community participation in the implementation of development is carried out by the community by maintaining, maintaining and preserving development. Langsa City Government involves all elements in the implementation of development activities. Ulemas, tengku, ustaz, lecturers and strategic groups actively participated in inviting the community to preserve the environment and uphold the practice of Islamic law in Aceh.

The community also participates in enjoying development. Langsa City is actively promoting the development of an Islamic and environmentally friendly city. From the efforts made so far, the community can enjoy development, because Langsa City is getting cleaner, more beautiful, safe and comfortable. Langsa City was made a community as an Islamic tourism destination, because there were a number of interesting tours available, such as protected forest tours, mangrove tours with quite reperentent worship facilities.

\subsection{Effective Communication Planning in Realizing the Development of Islamic and Environmentally Friendly Langsa City}

Creating City of Langsa as an Islamic city and environmentally friendly is the ideals of the Langsa City government that wants to be realized in the next 20 years. This was illustrated concretely in the Langsa City RPJP. To realize this goal is certainly not easy, because the development of the City of Langsa faces vis a vis with the social dynamics that continue to roll.

Based on field findings, the communication planning undertaken by Langsa City government has not been effective in realizing the development of an Islamic and environmentally friendly Langsa City. The strengths and opportunities of Langsa City government have not been utilized optimally to face the challenges, so that development has 
proceeded slowly. The effectiveness of the development goals of Langsa City is not effective, because the opportunities it has are not optimally utilized to cover weaknesses.

The slow achievement of the development goals of the Langsa City, is also caused by the low participation of some people to uphold Islamic law and maintain a clean environment, especially in some parts of the community that are in the suburbs.

This information is reinforced by the results of observations made, in some places, people are still littering. Trend of violations of Islamic law is still high, despite a decline in numbers. These habits are very closely related to the mental or ethos of people who are difficult to change, because it is already established with old values that are believed they. Muslims have not yet fully made the teachings of Islam the work ethic and the life ethic.

The effect of the mental weakness of the community, causing hampered development carried out. Religious teachings should ideally not only be used to pursue happiness in the hereafter, then to ignore worldly life. This is also what Max Webber affirmed in the Ethics of Prostestants, that the measure of world success is also a measure of success in the afterlife. Protestant Ethics is interpreted by Weber to be flexible, enthusiastic, earnest, and willing to give up material rewards. ${ }^{9}$

Cases of deviations in development carried out by individuals are also a picture of mental dynamics that need to be changed, so that development oriented towards realizing community welfare is achieved. Cases that continue to surface in the field and not optimal community support, must be an evaluation material for the Langsa City government to see comprehensively the root of the problem. The findings of researchers while in the field, see indications of the existence of a system that must be improved in Langsa City development communication planning.

Islamic communication planning needs to be confirmed by Langsa City government as an alternative approach in increasing community participation in development. Islamic communication is able to make a significant contribution to the development of Langsa City which is Islamic and environmentally friendly, because the practice of Islamic communication is very close to the socio-religious community of Langsa City. The importance of strengthening Islamic communication is illustrated as follows;

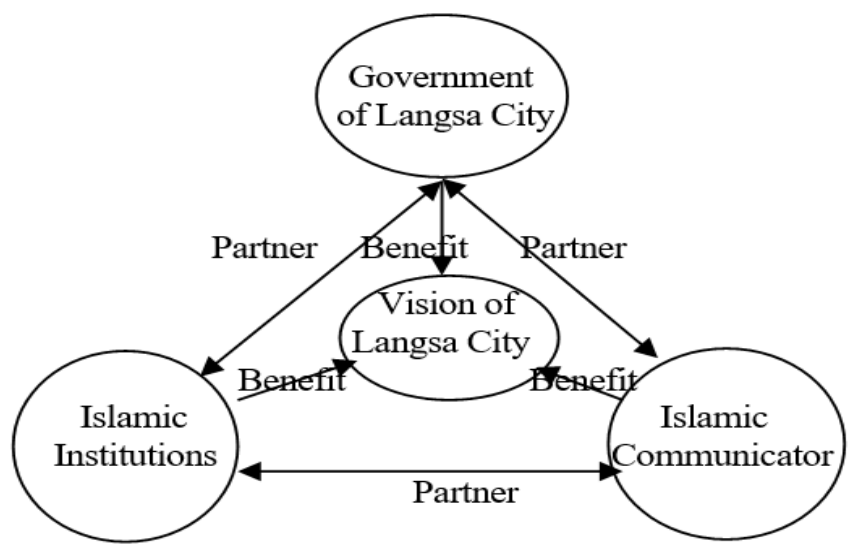

Figure 2. Partnership Model of Langsa City Government

${ }^{9}$ Max Weber, The Protestant Ethic and The Spirit of Capitalism (New York: Charles Scribner's Sons, 1958), p. 35. 
Based on the picture above, then in strengthening the implementation of Islamic communication, Langsa City government must empower Islamic institutions and Islamic communicators as a strategic partner in building an Islamic and environmentally friendly Langsa City. Mosque institutions, in addition to other institutions, are strategic channels for delivering development messages. At the personal and collective level, the doctrines of the development of the Islamic city of Langsa and environmentally friendly, systematically must be carried out by Langsa City Government in a sustainable manner. Quoting Mowlana, the mosque also became the most important channel of social communication and public communication and became the axis of the spiritual and cultural movements of the time of the Prophet Muhammad. The mosque is not only a means of purifying the soul, but at the same time seeking social knowledge and information.

Collaboration between the Langsa City government and Islamic institutions, the ulama, the preachers, the gampong village, the Board of Directors of the Mosque, the lecturers, the cleric, the tengku, the leader of the dayah, the recitation leader must be synergized. All of these elements are complementary elements and are equal partners of the Langsa City government to discuss the future of the Islamic and environmentally friendly Langsa City.

\section{Conclusion}

Langsa City Government carries out communication planning through four stages, namely mapping the problem, formulating a communication plan, establishing a strategy for implementing the communication plan and setting targets and objectives. Langsa City community actively participates in planning the development of an Islamic and environmentally friendly Langsa City. There are two forms of participation by the people of Langsa City, namely participating in planning and participating in development activities. Community participation in two forms, namely directly and indirectly. Direct participation is carried out by the community by involving themselves in the activities of the Development Planning Conference, FGD and public discussion. Participation in development activities, i.e. participating to maintain and preserve development. Communication planning by Langsa City government has not been effective. The ineffectiveness of development goals is due to the suboptimal use of the potential strengths and opportunities of Langsa City government. Likewise, the magnitude of the potential opportunities owned by Langsa City government have not been able to be optimized to overcome weaknesses and the magnitude of the potential strengths that have not been optimally utilized to overcome the challenges that arise. Public awareness to participate in development is still low. Promoting Islamic communication is a win-win solution in realizing the development of an Islamic city and environmentally friendly, because the Islamic approach is very close to the social community of Langsa City.

\section{References}

Creswell, John W. (1994). Research Design: Qualitative \& Quantitative Approach. California: Sage Publication.

Khambali, I. (2017). Model Perencanaan Vegetasi Hutan Kota. Yogyakarta: Penerbit Andi. 
Lincoln, Yvonna S. and Egon G. Guba. (1985). Naturalistic Inquiri. California: Sage Publications.

MacBride, Sean.(1980). Many Voices One World: Commnunication and Society Today and Tomorrow. London: Kogan Page.

Mowlana, Hamid. (1993). Komunikasi, Etika dan Tradisi Islam in Jurnal Audienta, Vol. 1, Nomor 1 Januari-Maret 1993. Bandung: Remaja Rosdakarya.

Mulyana, Dedy. (2004). Metode Penelitian Kualitatif: Paradigma baru Ilmu Komunikasi dan Ilmu Sosial Lainnya. Bandung: Remaja Rosdakarya.

Nasution, Zulkarimen. (2002). Komunikasi Pembangunan: Pengenalan Teori dan Penerapannya. Jakarta: PT. Raja Grafindo Persada.

Rakhmat, Jalaluddin. (1984). Metode Penelitian Komunikasi Dilengkapi Contoh Analisis Statistik. Bandung: Remaja Rosdakarya.

Rogers, Everett M. and F Ployd Shoemaker. (1981). Komunikasi Sambung Rasa. Jakarta: Pustaka Sinar Harapan.

Smith, Jonathan A. et.all. (2009). Interpretative Phenomenological Analysis: Theory, Method and Research. California: Sage Publications.

Weber, Max. (1958). The Protestant Ethic and The Spirit of Capitalism. New York: Charles Scribner's Sons. 